\title{
Konstruksi Kode Cross Bifix Bebas Ternair Untuk Panjang Ganjil
}

\author{
Moh. Affaf*, Zaiful Ulum** \\ * Prodi Pendidikan Matematika, STKIP PGRI Bangkalan \\ ** Prodi Pendidikan Matematika, STKIP PGRI Bangkalan
}

\begin{abstract}
ABSTRAK
Suatu kode cross bifix bebas dengan panjang $n$ adalah himpunan barisan dengan panjang $n$ dimana awalan (prefix) dengan panjang kurang dari $n$ dari suatu barisan tidak muncul sebagai akhiran (suffix) dari barisan yang lain. Studi tentang kode cross bifix bebas muncul dari permasalahan barisan terdistribusi sebagai solusi dari permasalahan sinkronisasi frame. Pada tahun 2012, untuk panjang barisan $n$ yang lebih dari 2, Stefano Bilotta mengkonstruksi kode cross bifix bebas biner dengan memanfaatkan lintasan Dyck. Satu tahun kemudian, yaitu pada 2013, Chee mengajukan konstruksi kode cross bifix bebas untuk sebarang simbol $q$ dan menamakan hasil konstruksinya sebagai $S_{q, n}^{k}$. Chee mengklaim bahwa kodenya optimal. Namun, keoptimalannya masih bergantung pada parameter $k$. Dua tahun kemudian, tepatnya pada 2015, Blackburn memperbaiki konstruksi Chee dengan menentukan parameter $k$ sehingga $S_{q, n}^{k}$ optimal. Dalam makalah ini, akan dikonstruksi kode cross bifix bebas ternair untuk panjang ganjil dengan memanfaatkan konstruksi kode cross bifix bebas milik Stefano Bilotta.
\end{abstract}

Katakunci: Barisan Terdistribusi, Bifix Bebas, Kode Cross Bifix Bebas, Lintasan Dyck

\section{Pendahuluan}

Dalam sistem komunikasi, dikenal apa yang disebut Frame Synchronization. Dalam sistem ini, untuk menjamin adanya keselarasan diantara transmitter dan receiver pada frame data yang dipancarkan, disisipkan kata penyelaras secara periodik ke dalam aliran data. Karena data dipancarkan secara berulang-ulang, receiver perlu mengetahui kapan aliran data dimulai. Dalam hal ini, kata penyelaras berperan sebagai penanda pada frame yang mana data dimulai dan permulaan dari pesan yang dikirimkan.

Metoda sinkronisasi frame ini tidak hanya berguna dalam sistem komunikasi. Dalam disertasinya, Weindl [9] berhasil menunjukkan bahwa metoda sinkronisasi dapat digunakan untuk memodelkan gene expression (sintesis protein). Serupa dengan kata penyelaras, alam menggunakan suatu barisan tertentu untuk menandai dimulainya wilayah DNA yang fundamental. Analogi ini 
memungkinkan penggunaan teknik pada sinkronisasi frame dengan menggunakan simulasi pada genome yang telah tersedia.

Dalam teknik sinkronisasi, receiver dilengkapi dengan alat pendeteksi pola untuk dapat mengenali kata penyelaras. Massey [7] menjelaskan suatu prosedur yang optimal untuk mencari kata penyelaras dalam suatu aliran data pada Gaussian Channel. Massey menyadari bahwa prosedur pencarian ditentukan oleh bentuk kata penyelaras yang dipilih meskipun dalam analisisnya dia tidak meninjau hal tersebut. Setahun kemudian, yakni di tahun 1973, Nielsen [8] menunjukkan bahwa ekspektasi dari pencarian kata penyelaras dapat diminimumkan jika kata penyelaras yang diambil memiliki sifat bebas imbuhan (bifix free). Ini merupakan paper pertama dimana terminologi Bifix Free diperkenalkan. Suatu kata p dikatakan bebas imbuhan jika tidak ada akhiran sejati dari p yang muncul sebagai awalan dari p.

Dalam perkembangan lebih lanjut, metoda sinkronisasi frame dapat dilakukan dengan mengirimkan data-data yang berasal dari kode $\left\{x_{1}, x_{2} x_{3}, \ldots, x_{k}\right\}$ yang mempunyai sifat khusus. Agar permulaan dari suatu data frame dapat dikenali, kita harus memastikan bahwa semua akhiran sejati dari $x_{i}$ tidak muncul sebagai awalan dari $x_{j}$ untuk setiap $x_{i}$ dan $x_{j}$ anggota $\left\{x_{1}, x_{2} x_{3}, \ldots, x_{k}\right\}$. Metode ini diperkenalkan oleh Wijngaarden dan Willink [5] pada tahun 2000. Kode yang seperti ini disebut kode cross bifix bebas.

Mengingat potensi praktikal dari himpunan/kode cross bifix bebas, beberapa peneliti mengusulkan beberapa cara untuk mengontruksi himpunan tersebut. Pertama, Bajic [1] mengkontruksi kode cross bifix bebas dengan menggunakan metode yang dia sebut Metode Kernel Set. Kemudian, pada 2012 Bilotta [2] memperkenalkan kontruksi kode cross bifix bebas dengan panjang sebarang. Kode yang dihasilkan Bajic maupun Bilotta, keduanya adalah kode biner. kontruksi kode cross bifix bebas dengan menggunakan alphabet yang mempunyai $q$ simbol baru diperkenalkan di tahun 2013 oleh Chee [4] dan kemudian metoda tersebut diperumum oleh Blackburn [3] di tahun 2015.

\section{Penelitian Terdahulu}


Mengingat goal dari penelitian ini adalah memperluas Konstruksi Bilotta, maka kajian pustaka ini akan ditutup dengan konstruksi kode cross bifix bebas biner oleh Stefano Bilotta [2] pada tahun 2012. Bilotta mengkonstruksi kode cross bifix bebas biner dengan memanfaatkan lintasan Dyck. Dalam konstruksinya, Bilotta membagi kode yang dikonstruksinya menjadi tiga bagian, yaitu untuk panjang kode ganjil, panjang kode ganjil dengan parameter genap, dan panjang kode genap dengan parameter ganjil. Dari konstruksinya ini, Bilotta memperoleh hasil bahwa $\operatorname{CBFS}_{2}(n)$ adalah himpunan cross bifix bebas yang tak dapat diperluas di $H_{2}(n)$, yaitu himpunan kata kode biner dengan panjang $n$, artinya setiap diambil $h$ anggota $H_{2}(n)$ yang bukan anggota $\operatorname{CBFS}_{2}(n)$, maka himpunan $\mathrm{CBFS}_{2}(n) \cup\{h\}$ bukan lagi himpunan cross bifix bebas.

\subsection{Konstruksi $\mathrm{CBFS}_{2}(2 m+1)$}

Kode cross bifix bebas $\operatorname{CBFS}_{2}(2 m+1)$ didefinisikan oleh Bilotta sebagai himpunan

$$
\operatorname{CBFS}_{2}(2 m+1)=\left\{x \alpha: \alpha \in D_{2 m}\right\},
$$

yaitu himpunan lintasan dengan panjang $2 m+1$ yang diawali dengan langkah naik yang kemudian diteruskan dengan lintasan Dyck dengan panjang $2 m$. Tentu saja, kardinalitas dari $C_{B F}(2 m+1)$ adalah $C_{m}$, Bilangan Catalan ke- $m$. Gambar 2.1 berikut memberikan gambaran himpunan $C_{B F S_{2}}(2 m+1)$ secara geometris.

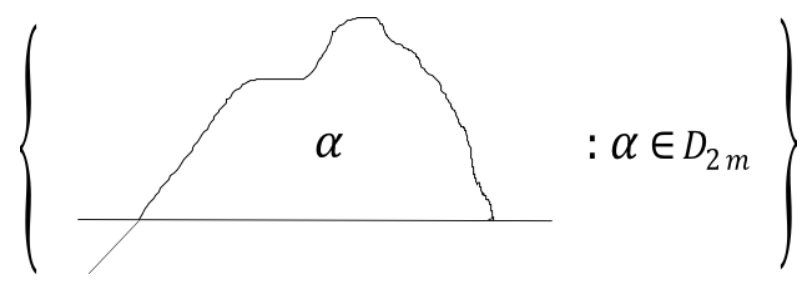

Gambar 2.1. $C B F S_{2}(2 m+1)$ secara geometris

Selain itu, Gambar 2.2 berikut memberikan gambaran bagaimana Konstruksi Bilotta menghasilkan kode $\operatorname{CBFS}_{2}(7)$, yaitu himpunan kata/katakode $\{1111000,1101100,1110010,1110100,1101010\}$.

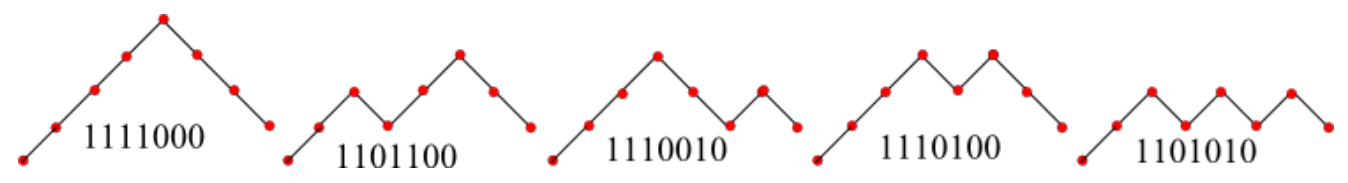


Dari konstruksi $\mathrm{CBFS}_{2}(2 m+1)$, Bilotta memperoleh hasil berikut.

Teorema 2.1.[2] $\mathrm{CBFS}_{2}(2 m+1)$ adalah kode cross bifix bebas dengan kardinalitas $C_{m}$ yang tak dapat diperluas di $H_{2}(2 m+1)$.

\subsection{Konstruksi $\mathrm{CBFS}_{2}(2 m+2)$ dengan $m$ genap}

Kode cross bifix bebas $\operatorname{CBFS}_{2}(2 m+2)$ untuk $m$ genap didefinisikan oleh Bilotta sebagai himpunan

$$
\operatorname{CBFS}_{2}(2 m+2)=\left\{\alpha x \beta \bar{x}: \alpha \in D_{2 i}, \alpha \in D_{2(m-i)}, 0 \leq i \leq \frac{m}{2}\right\},
$$

yaitu himpunan lintasan dengan panjang $2 m+2$ yang diawali dengan lintasan Dyck dengan panjang $2 i$, diikuti dengan langkah naik, lalu dilanjutkan dengan lintasan Dyck dengan panjang 2(m-i), kemudian diakhiri dengan langkah turun. Tentu saja, kardinalitas dari $C_{B F S_{2}}(2 m+2)$ untuk $m$ genap ini adalah $\sum_{i=0}^{\frac{m}{2}} C_{m} C_{m-i}$. Gambar 2.2 berikut memberikan gambaran himpunan CBFS $_{2}(2 m+1)$ secara geometris.

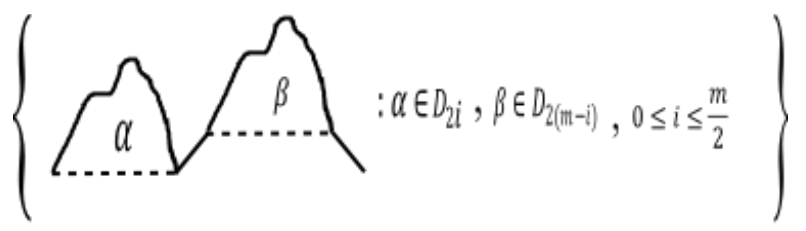

Gambar 2.3.2.1. $\mathrm{CBFS}_{2}(2 m+2)$ dengan $m$ genap secara geometris

Selain itu, Gambar 2. 2 berikut memberikan gambaran bagaimana Konstruksi Bilotta menghasilkan kode $\mathrm{CBFS}_{2}(6)$, yaitu himpunan kata/katakode $\{111000,110100,101100\}$.

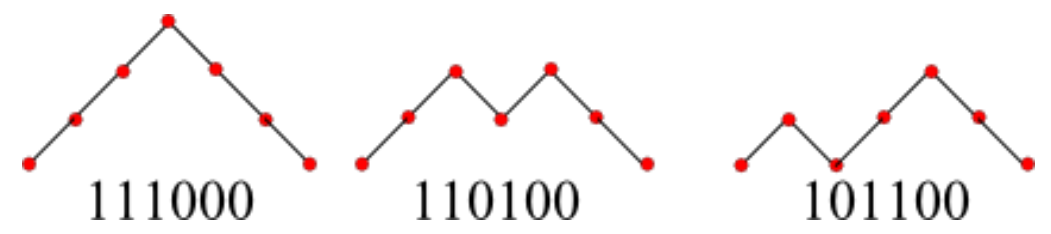

Gambar 2..2. Semua katakode di $\mathrm{CBFS}_{2}(6)$ 
Dari konstruksi $\mathrm{CBFS}_{2}(2 m+2)$ untuk $m$ genap ini, Bilotta memperoleh hasil berikut.

Teorema 2.2. [2] $C B F S_{2}(2 m+2)$ untuk $m$ genap adalah kode cross bifix bebas dengan kardinalitas $\sum_{i=0}^{\frac{m}{2}} C_{i} C_{m-i}$ yang tak dapat diperluas di $H_{2}(2 m+2)$.

\subsection{Konstruksi $\mathrm{CBFS}_{2}(2 m+2)$ dengan $m$ ganjil}

Kode cross bifix bebas $\mathrm{CBFS}_{2}(2 m+2)$ untuk $m$ ganjil didefinisikan oleh Bilotta sebagai himpunan

$$
\begin{gathered}
\operatorname{CBFS}_{2}(2 m+2)=\left\{\alpha x \beta \bar{x}: \alpha \in D_{2 i}, \alpha \in D_{2(m-i)}, 0 \leq i \leq \frac{m+1}{2}\right\} \\
\backslash\left\{x a \bar{x} x \beta \bar{x}: \alpha \in D_{2 i}, \alpha \in D_{2(m-1)}\right\},
\end{gathered}
$$

yaitu himpunan lintasan dengan panjang $2 m+2$ yang diawali dengan lintasan Dyck dengan panjang $2 i$, diikuti dengan langkah naik, lalu dilanjutkan dengan lintasan Dyck dengan panjang $2(m-i)$, kemudian diakhiri dengan langkah turun; setelah semua lintasan ini terkumpul, maka Bilotta membuang semua lintasan yang diawali dengan langkah naik yang dilanjutkan dengan lintasan Dyck dengan panjang $m-1$, diikuti dengan langkah turun, lalu diikuti langkah naik, lalu dilanjutkan dengan lintasan Dyck dengan panjang $m-1$, kemudian diakhiri dengan langkah turun. Tentu saja, kardinalitas dari $\operatorname{CBFS}_{2}(2 m+2)$ untuk $m$ ganjil ini adalah $\sum_{i=0}^{\frac{m}{2}} C_{i} C_{m-i}-C_{\frac{m-1}{2}}^{2}$.

Gambar 2.3 berikut memberikan gambaran himpunan $C_{B F}(2 m+2)$ untuk $m$ ganjil secara geometris.

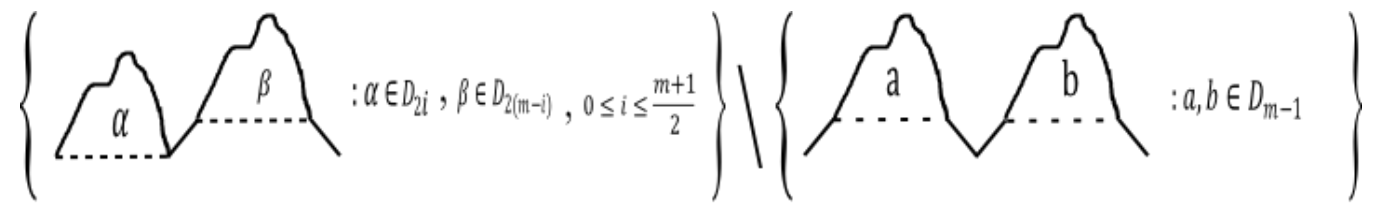

Gambar 2.3. $\mathrm{CBFS}_{2}(2 m+2)$ dengan $m$ ganjil secara geometris

Selain itu, Gambar 2.3 berikut memberikan gambaran Konstruksi Bilotta menghasilkan kode $\quad \mathrm{CBFS}_{2}(8), \quad$ yaitu $\{11110000,11011000,11100100,11101000,11010100,10111000\} \cup$ $\{10110100,10101100\}$. 


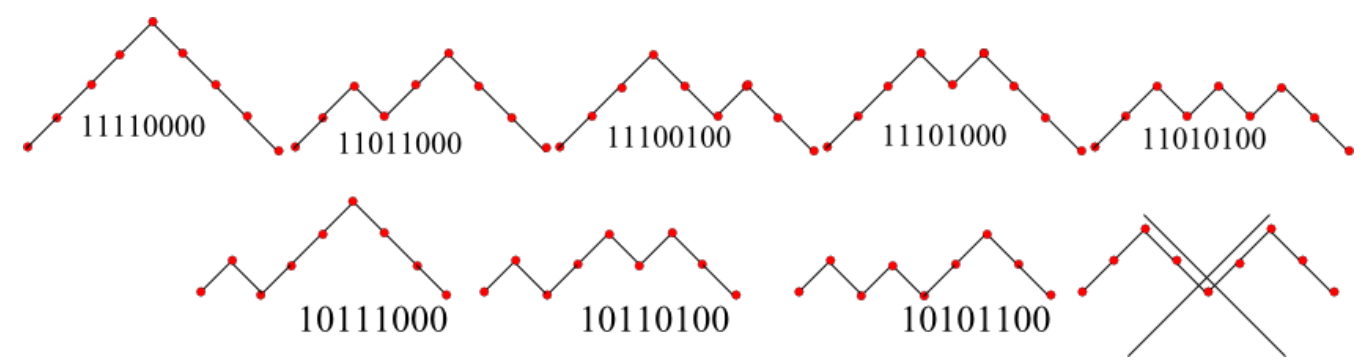

Gambar 2.3. Semua katakode di $\mathrm{CBFS}_{2}(8)$

Dari konstruksi $\mathrm{CBFS}_{2}(2 m+2)$ untuk $m$ ganjil ini, Bilotta memperoleh hasil berikut.

Teorema 2.3. [2] $\mathrm{CBFS}_{2}(2 m+2)$ untuk $m$ ganjil adalah kode cross bifix bebas berkardinalitas $\sum_{i=0}^{\frac{m+1}{2}} C_{i} C_{m-i}-C_{\frac{m-1}{2}}^{2}$ yang tak dapat diperluas di $H_{2}(2 m+2)$.

\section{Konstruksi $\mathrm{CBFS}_{3}(2 \mathrm{~m}+1)$}

Dalam bagian ini akan dikaji mengenai metoda perluasan konstruksi Bilotta untuk panjang ganjil sehingga menjadi Kode Cross Bifix Bebas ternair, yaitu kode cross bifix bebas dengan 3 simbol. Adapun sifat-sifat yang akan ditinjau dari perluasan ini adalah himpunan yang dibentuk adalah Himpunan Cross Bifix Bebas dan kardinalitasnya masih terkait pula dengan Bilangan Catalan ke- $m$. Bagian ini akan dibagi menjadi dua, yaitu bagian ide konstruksi untuk panjang ganjil dan bagian klaim bahwa konstruksi tersebut adalah cross bifix bebas ternair. Sebagai catatan, pada konstruksi ini, langkah naik pada konstruksi Bilotta disimbolkan dengan 0 dan langkah turun disimbolkan dengan 1.

\subsection{Ide Konstruksi}

Berikut ini adalah metoda/konstruksi untuk memperluas konstruksi Bilotta untuk panjang ganjil ke Kode Cross Bifix Bebas ternair.

Konstruksi 3.1.1. Misalkan $\mathrm{CBFS}_{2}(2 m+1)$ adalah Kode Cross Bifix Bebas dengan panjang ganjil hasil konstruksi Bilotta. Perluasan $C_{B F S_{2}}(2 m+1)$ menjadiCBFS $3(2 m+1)$ adalah sebagai berikut.

i) Semua anggota $C_{B F S}(2 m+1)$ dijadikan anggota $C B F S_{3}(2 m+1)$.

ii) Semua anggota $H_{3}(2 m+1)$ yang dapat diperoleh dari anggota $C B F S_{2}(2 m+$ 1) dengan cara mengganti 0 dengan 2 , juga dijadikan anggota $C_{B F S_{3}}(2 m+$ 1). 
Seperti yang telah diketahui sebelumnya dari konstruksi Bilotta, CBFS $_{2}(5)=\{00011,00101\}$. Selanjutnya, semua kemungkinan mengganti simbol 0 pada 00011 dengan 2 adalah 00011; 20011; 02011; 00211; 22011; 20211; 02211; 22211 dan semua kemungkinan mengganti simbol 0 pada 00101 dengan 2 adalah 00101; 20101; 02101; 00121; 22101; 20121; 02121; 22121, sehingga diperoleh himpunancross bifix bebas ternair dengan panjang 5, CBFS $_{3}(5)=\{00011,20011,02011,00211,22011,20211,02211,22211\} \cup$ $\{00101,20101,02101,00121,22101,20121,02121,22121\}$.

Jika diperhatikan dengan seksama, semua anggota $C_{B F}(5)$ sama dengan barisan yang terbentuk dengan mengisi semua posisi 0 pada barisan di $\mathrm{CBFS}_{2}(5)$ dengan semua kemungkinan simbol genap di $\{0,1,2\}$.

\subsection{Himpunan Cross Bifix Bebas $\mathrm{CBFS}_{3}(2 m+1)$}

Dengan memperhatikan tinjauan pada bagian akhir subbagian sebelumnya, diperoleh Kontruksi 3.2.1 berikut yang selanjutnya akan diklaim sebagai hasilnya merupakan himpunan cross bifix bebas.

Konstruksi 3.2.1. Misalkan $\omega=\omega_{1} \omega_{2} \omega_{3} \ldots \omega_{2 m+1}$ anggota $\operatorname{CBFS}_{2}(2 m+1)$. Selanjutnya, definisikan $\mathbf{0}_{\omega}=\left\{i \in[n]: \omega_{i}=0\right\}$ dan yaitu himpunan semua posisi di $\omega$ yang bersimbol 0 . Himpunan ternair $\operatorname{CBFS}_{3}(2 m+1)$ didefinisikan sebagai

$$
\operatorname{CBFS}_{3}(2 m+1)=\bigcup_{\omega \in C B F S_{2}(2 m+1)} C_{\omega, 3}^{2 m+1}
$$

dimana

$$
C_{\omega, 3}^{2 m+1}=\left\{c \in H_{3}(2 m+1): c_{i}=0 \vee c_{i}=2, \forall_{i \in \mathbf{0}_{\omega}}\right\}
$$

Yaitu Himpunan barisan ternair yang posisi ke- $i$-nya bersimbol genap di $\{0,1,2\}$ jika posisi tersebut bersimbol 0 di $\omega$.

Sebagai contoh, jika ingin membentuk $C_{B F S_{3}}(3)$ maka cukup melihat $C B F S_{2}(3)$. Karena $\operatorname{CBFS}_{2}(3)=\{001\}$, maka $\mathbf{0}_{001}=\{1,2\}$. Oleh karena itu, anggota $\mathrm{CBFS}_{3}(3)$ adalah barisan ternair dengan panjang 3 yang dua posisi pertamanya bersimbol genap di $\{0,1,2\}$, yaitu 0 . Sehingga, akan diperoleh hasil, yaitu $\operatorname{CBFS}_{3}(3)=\{001,201,021,221\}$. 
selanjutnya, akan ditunjukkan bahwa himpunan $\operatorname{CBFS}_{3}(2 m+1)$ pada Konstruksi 3.2.1 tidak hanya himpunan barisan ternair hasil perluasan Konstruksi Bilotta, tetapi $\mathrm{CBFS}_{3}(2 m+1)$ juga merupakan Himpunan Cross Bifix Bebas. Hasil ini ditetapkan dalam Teorema 3.2.2 berikut.

Teorema 3.2.2. Himpunan $C_{B F}(2 m+1)$ adalah Himpunan/Kode Cross Bifix Bebas dengan kardinalitas $2^{m+1} C_{m}$.

Bukti. Karena $\operatorname{CBFS}_{2}(2 m+1)$ adalah himpunan lintasan latis yang diawali langkah naik yang diikuti lintasan Dyck dengan panjang $2 m$, maka untuk setiap $0<k<n$ berlaku $\mid$ pre $\left._{k} \omega\right|_{0}>\mid$ pre $\left._{k} \omega\right|_{1}$ dan $\left|s u f_{k} \gamma\right|_{0} \leq\left|s u f_{k} \gamma\right|_{1}$ untuk setiap $\omega$ dan $\gamma$ di $C_{B F S}(2 m+1)$. Karena simbol genap pada barisan di $\operatorname{CBFS}_{3}(2 m+1)$ menempati posisi yang sama dengan posisi simbol 0 pada barisan di himpunan $C B F S_{2}(2 m+1)$, maka untuk $0<k<$ $n$ berlaku

$$
\left|\operatorname{pre}_{k} \alpha\right|_{0}+\mid \text { pre }\left._{k} \alpha\right|_{2}>\mid \text { pre }\left._{k} \alpha\right|_{1} \ldots(*)
$$

dan

$$
\left|s u f_{k} \beta\right|_{0}+\left|s u f_{k} \beta\right|_{2} \leq\left|s u f_{k} \beta\right|_{1} \ldots(* *)
$$

untuk setiap $\alpha$ dan $\beta$ di $\operatorname{CBFS}_{3}(2 m+1)$.

Sekarang, andaikan $\mathrm{CBFS}_{3}(2 m+1)$ bukan himpunan cross bifix bebas, maka ada $\bar{\alpha}$ dan $\bar{\beta}$ di $C_{B F S_{3}}(2 m+1)$ sehingga untuk suatu $k$ yang berada di $0<k<n$ berlaku $\operatorname{pre}_{k} \bar{\alpha}=\operatorname{suf}_{k} \bar{\beta}$. Akibatnya, berlaku $\left|\operatorname{pre}_{k} \bar{\alpha}\right|_{t}=$ $\left|s u f_{k} \bar{\beta}\right|_{t}$ untuk setiap $t$ di $[q]$. Akibatnya, dengan menggunakan persamaan $(*)$, diperoleh

$$
\mid \text { suf }\left._{k} \beta\right|_{0}+\mid \text { suf }\left._{k} \beta\right|_{2}=\mid \text { pre }\left._{k} \alpha\right|_{0}+\mid \text { pre }\left._{k} \alpha\right|_{2}>\mid \text { pre }\left._{k} \alpha\right|_{1}=\mid \text { suf }\left._{k} \beta\right|_{1}
$$

Namun, hal ini kontradiksi dengan persamaan $(* *)$.

Jadi haruslah $\mathrm{CBFS}_{3}(2 m+1)$ adalah himpunan cross bifix bebas.

Terakhir, karena banyaknya cara mengganti simbol 0 sebanyak $t$ dengan simbol 2 pada setiap anggota $C_{B F S}(2 m+1)$ adalah sebanyak $\left(\begin{array}{c}m+1 \\ t\end{array}\right)$ untuk setiap $t=0,1,2,3, \ldots, m+1$ dan anggota $C B F S_{2}(2 m+1)$ sebanyak $C_{m}$, maka diperoleh kardinalitas dari $\operatorname{CBFS}_{3}(2 m+1)$ adalah 


$$
\begin{aligned}
\mid \operatorname{CBFS}_{3}(2 m & +1) \mid=\underbrace{\left(\begin{array}{c}
m+1 \\
1
\end{array}\right)+\cdots+\left(\begin{array}{c}
m+1 \\
m+1
\end{array}\right)}_{\left(\begin{array}{c}
m+1 \\
0
\end{array}\right)+\left(\begin{array}{c}
m+1 \\
1
\end{array}\right)+\cdots+\left(\begin{array}{c}
m+1 \\
m+1
\end{array}\right)+\cdots+\left(\begin{array}{c}
m+1 \\
1
\end{array}\right)+\cdots+\left(\begin{array}{c}
m+1 \\
m+1
\end{array}\right) \operatorname{sebanyak} C_{m}} \\
= & {\left[\left(\begin{array}{c}
m+1 \\
0
\end{array}\right)+\left(\begin{array}{c}
m+1 \\
1
\end{array}\right)+\left(\begin{array}{c}
m+1 \\
2
\end{array}\right)+\left(\begin{array}{c}
m+1 \\
3
\end{array}\right)+\cdots+\left(\begin{array}{c}
m+1 \\
m+1
\end{array}\right)\right] C_{m} } \\
& =2^{m+1} C_{m} .
\end{aligned}
$$

\section{Kesimpulan}

Dari hasil penelitian ini, diperoleh kesimpulan bahwa Kode Cross Bifix Bebas hasil Konstruksi Bilotta untuk panjang ganjil, $C_{B F S_{2}}(2 m+1)$, dapat diperluas menjadi Kode Cross Bifix Bebas Ternair, $C_{B F S_{3}}(2 m+1)$. Hal pertama yang dilakukan mengaitkan langkah naik dari lintasan di $\operatorname{CBFS}_{3}(2 m+1)$ dengan simbol 0 dan mengaitkan langkah turunnya dengan simbol 1. Kemudian, semua posisi simbol 0 diisi dengan semua kemungkinan simbol genap di $\{0,1,2\}$.

\section{Daftar Pustaka}

[1] Dragana Bajic and Tatjana Loncar-Turukalo. A simple suboptimal construction of cross-bifix-free codes. Cryptography and Communications, $6(1): 27$

[2] Bilotta, S., Pergola, E., \& Pinzani, R. (2012). A new approach to crossbifix-free sets. IEEE Transactions on Information Theory, 58(6), 40584063.

[3] Blackburn, S. R. (2015). Non-overlapping codes. IEEE Transactions on Information Theory, 61(9), 4890-4894.

[4] Chee, Y. M., Kiah, H. M., Purkayastha, P., \& Wang, C. (2013). Crossbifix-free codes within a constant factor of optimality. IEEE Transactions on Information Theory, 59(7), 4668-4674.

[5] Van Wijngaarden, A. D. L., \& Willink, T. J. (2000). Frame synchronization using distributed sequences. IEEE Transactions on Communications, 48(12), 2127-2138.

[6] Emeric Deutsch. Dyck path enumeration. Discrete Mathematics,204(1):167 
[7] James L Massey. Optimum frame synchronization. Communications, IEEE Transactions on, 20(2):115

[8] Peter Tolstrup Nielsen. On the expected duration of a search for a _xed pattern in random data. IEEE Transactions on Information Theory, 19(5):702

[9] Johanna Weindl. Frame synchronization processes in gene expression. Verlag Dr. Hut, 2008. 